\title{
FORMULASI OBAT KUMUR GAMBIR DAN UJI EFEKTIVITAS TERHADAP BAKTERI Staphylococcus aureus
}

\section{Zola Efa Harnis, Aldrina Ginting, Christica Illsanna, Bunga Rimnta Barus, Linda Margata}

Fakultas Farmasi Institut Kesehatan Deli Husada Deli Tua e-mail : zolaharnis@gmail.com

\begin{abstract}
Oral hygiene and dental health are very important, Because many products are used to maintain cleanliness and dental health. In the oral cavity and teeth, there are various kinds of patogen bacteria in the oral cavity, including the bacteria that cause thrush, Staphylococcus aureus. Gambir is the result of extraction containing polyphenol compounds. The main components contained in gambir consist of alkaloids, flavonoids, tannins and saponins. The use of gambir as a mouthwash preparation is an alternative to replace mouthwash preparations which generally contain an antiseptic in the form of alcohol which can trigger oral cancer. This research is to formulate gambir as a mouthwash and determine the differences in the effectiveness of antibacterial on the growth of Staphylococcus aureus with variations in the concentration of $5 \%, 10 \%, 15 \%$. Antibacterial activity test using NA media with agar diffusion method. Physical requirements tests include organoleptic tests, $\mathrm{pH}$ tests and viscosity testsshowed that the preparation of $5 \%, 10 \%$ and $15 \%$ gambir mouthwash had a $\mathrm{pH}$ outside the optimum bacterial growth range of 5. Viscosity of mouthwash preparations of 1.30-5.10 Cp. The antibacterial activity of Staphylococcus aureus in $F 1$ did not produce inhibitory zones, F2 was $5.46 \mathrm{~mm}$, F3 was $9.60 \mathrm{~mm}$ and F4 was 10.76 $\mathrm{mm}$ while in f5 the positive control was $12.10 \mathrm{~mm}$. Conclusio of this study is gambier mouthwash concentration of 5\%,10\% and $15 \%$ can inhibit the growth of staphylococcus aureus bacteria.
\end{abstract}

Keywords: Antibacterial effectiveness, Gambir, Staphylococcus aureus.

\section{PENDAHULUAN}

Ada banyak masalah mulut dan gigi yang terjadi karena kurang menjaga kesehatan mulut, kebersihan mulut dan kesehatan gigi sangat penting dalam kehidupan seseorang dalam kehidupannya sehari-hari (hidayat, 2016).
Beberapa masalah mulut yang sering terjadi yaitu bau mulut, sariawan dan infeksi mulut, selain itu ditemukan pula masalah lain seperti mulut kering, radang gusi dan kanker mulut (Almasyhuri dkk, 2018). Sariawan adalah luka yang ada di dalam mulut, biasanya berbentuk oval atau bulat berwarna 
putih dan menimbulkan rasa sakit serta tidak nyaman.

Sariawan dapat disebakan oleh beberapa hal, diantaranya adalah kurangnya vit C, vit B12 dan bisa juga karena adanya infeksi yang disebabkan oleh bakteri, virus, atau jamur. Selain itu, sariawan juga dapat disebabkan oleh luka pada mulut akibat tergigit atau mengkonsumsi sesuatu yang keras atau tajam. Luka - luka kecil tersebut menjadi tempat berkembangnya bagi bakteri (sandy dkk, 2018). Obat kumur adalah formulasi berupa larutan, umumnya dalam larutan pekat yang harus diencerkan terlebih dahulu sebelum digunakan, yang bertujuan untuk penggunaan sebagai pencegahan atau pengobatan infeksi tenggorokan (syamsuni, 2017).

Menurut definisi lain, obat kumur yaitu larutan yang biasanya mengandung bahan penyegar nafas, astringen, demulsen, atau surfaktan, atau antibakteri untuk menyegarkan dan membersihkan saluran pernafasan yang pemakaiannya dengan berkumur (Anastasia dkk, 2016).

Gambir adalah sejenis getah yang dikeringkan dan berasal dari ekstrak remasan daun dan ranting tumbuhan gambir (Uncaria gambir Roxb.). Setelah menggalami proses pengekstrakan, bentuk gambir akan seperti kue kering dengan warna putih, kuning, atau kecoklatan. Gambir merupakan hasil ekstraksi yang mengandung senyawa polifenol (aditya dkk, 2016).
Senyawa polifenol gambir adalah sebagai (+) katekin yang merupakan senyawa alami dari tanaman yang mempunyai beberapa peranan, salah satu perannya antara lain sebagai senyawa antibakteri. Kemampuannya sebagai antibakteri disebabkan polifenol mudah berikatan dengan senyawa organik lain terutama protein. Terbentuknya senyawa kompleks menyebabkan fungsi dan peranan senyawa tersebut menjadi berkurang bahkan menyebabkan kebocoran dan kematian sel (Pambayun dkk, 2018).

Berdasarkan

kandungan metabolit sekunder yang terkandung didalam gambir yang berpotensi sebagai obat kumur maka peneliti ingin melakukan peneltian yang berjudul formulasi obat kumur gambir dan uji efektifitas terhadap bakteri Staphylococcus aureus.

\section{METODE}

Penelitian ini dilakukan secara eksperimental yang meliputi tahapan, identfikasi sampel, pemeriksaan skrining fitokimia, karakterisasi simplisia, pembuatan sediaan obat kumur, uji efektivitas bakteri, evaluasi sediaan obat kumur.

Formulasi sediaan obat kumur gambir di lakukan diLaboratoium Teknologi Sediaan Farmasi satu dan pengamatan efektivitas terhadap bakteri di lakukan di Laboratorium Mikrobiologi Fakultas Farmasi Institut Kesehatan Deli Husada Deli Tua. Sampel gambir yang di gunakan dalam penelitian ini diperoleh dari pasar Delitua. 
Pengambilan sampel yang dilakukan secara purposive sampling dimana peneliti memperoleh sampel secara sengaja sesuai dengan persyaratan sampel yang diperlukan.

\section{Uji kemurnian gambir}

Gambir murni ditandai dengan tidak adanya urea dalam gambir. Jika terbentuk endapan hablur putih maka simplisia yang digunakan positif mengandung urea

\section{Evaluasi sediaan obat} kumur

Evaluasi formula yang dilakukan meliputi evaluasi fisik dan biologi. Evaluasi fisik meliputi pemeriksaan stabilitas sediaan, penentuan $\mathrm{pH}$ dan uji viskositas. Evaluasi biologi meliputi penentuan aktivitas antibakteri sediaan obat kumur-kumur ekstrak etanol gambir terhadap bakteri Staphylococcus aureus dengan metode difusi agar (Ningrum dkk, 2018).

\section{a. Uji makroskopis}

Pemeriksaan

terhadap sediaan obat kumur ekstrak gambir, yaitu pemeriksaan terhadap warna, aroma, dan homogenitas. Parameter ini merupakan ciri visual dan karakteristik fisik yang dapat diamati secara langsung (Ningrum dkk, 2018).

\section{b. Pengukuran pH}

Pengukuran $\mathrm{pH}$ dilakukan dengan menggunakan kertas $\mathrm{pH}$ universal. Kertas $\mathrm{pH}$ universal dicelupkan ke dalam mouthwashselama beberapa menit kemudian dicocokan dengan warna indicator (Ningrum dkk, 2018), atau juga bias menggunakan $\mathrm{pH}$ elektrik.

\section{c. Pengukuran viskositas}

Sebanyak $50 \mathrm{ml}$ mouthwash ke dalam gelas ukur $250 \mathrm{ml}$ kemudian viskositasnya diukur dengan Viskometer menggunakan spindle dan kecepatan yang ditentukan.Sesuai indicator (Ningrum dkk, 2018), atau juga bias menggunakan $\mathrm{pH}$ elektrik.

\section{Pengujian efektivitas} antibakteri dalam formulasi obat kumur gambir

Pengujian aktivitas antibakteri mengunakan metode difusi. Cawan diinkubasi selama 48 jam pada suhu $37{ }^{\circ} \mathrm{C}$ dan dihitung jumlah koloni Staphylococcus aureus yang tumbuh pada media NA.

\section{HASIL DAN PEMBAHASAN}

Tabel 1. Hasil uji kemurnian gambir

\begin{tabular}{|c|c|c|c|c|}
\hline $\begin{array}{l}\text { Seny } \\
\text { awa }\end{array}$ & aksi ${ }^{\text {Pre }}$ & asil ${ }^{\mathrm{H}}$ & an & Kesimpul \\
\hline Urea & O3 & - & & (-) Urea \\
\hline
\end{tabular}

Keterangan : (+) mengandung senyawa

(-) tidak mengandung senyawa

Dari tabel 1 diatas sampel gambir yang akan digunakan sebagai obat kumur yang terdapat di pasar tradisional Delitua secara purposive sampling yang digunakan adalah gambir 


\section{Evaluasi sediaan obat kumur \\ a. Hasil pengamatan makroskopis \\ Pemeriksaan organoleptis terhadap sediaan obat kumur gambir}

Kemudiaan, dilakukan pemeriksaan terhadap warna, aroma, dan homogennitas. Ketiga parameter tersebut merupakan ciri visual dan karakteristik fisik yang dapat diamati langsung

Tabel 2. Formulasi obat kumur gambir

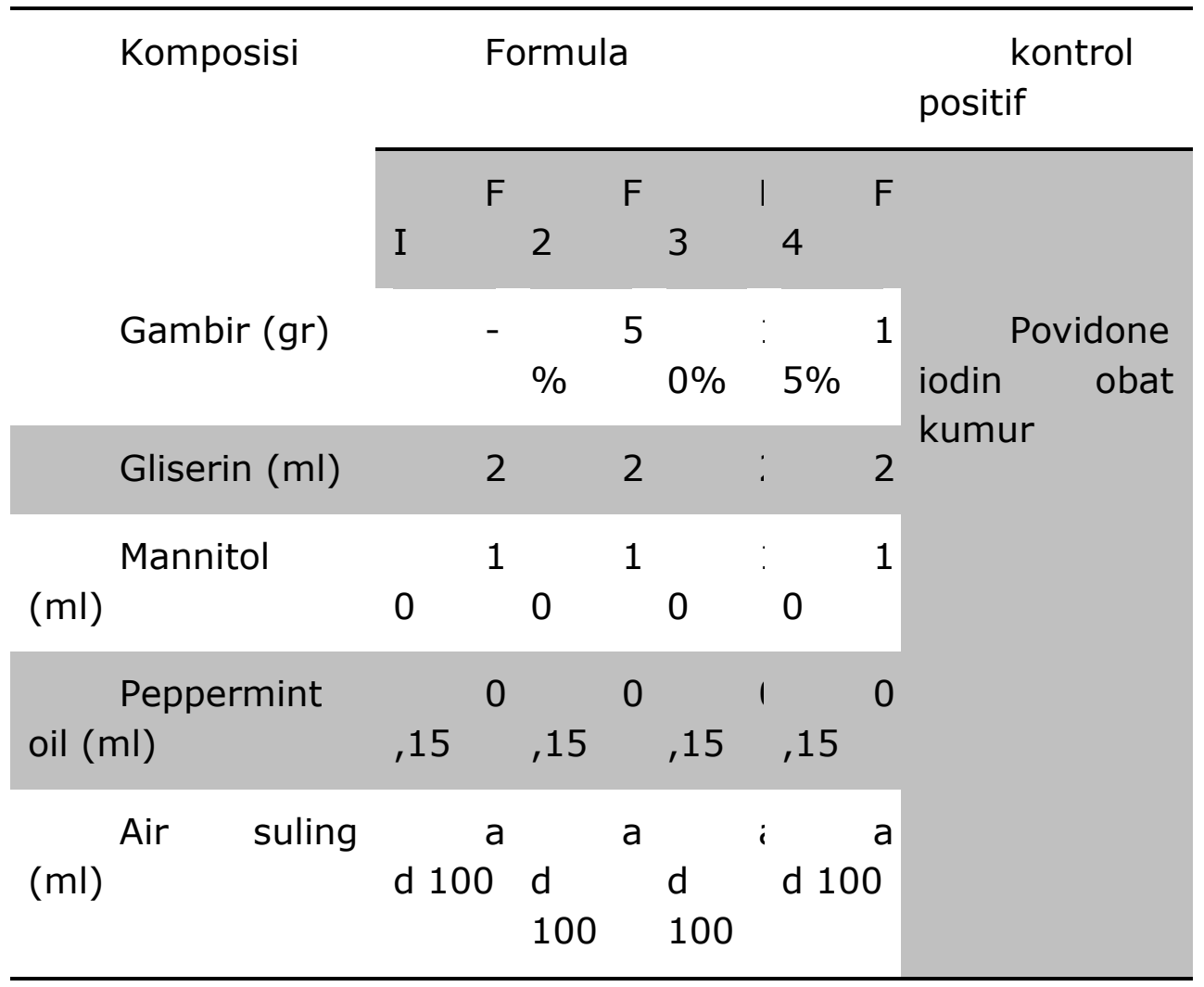

Tabel 3. Hasil pengamatan makroskopis

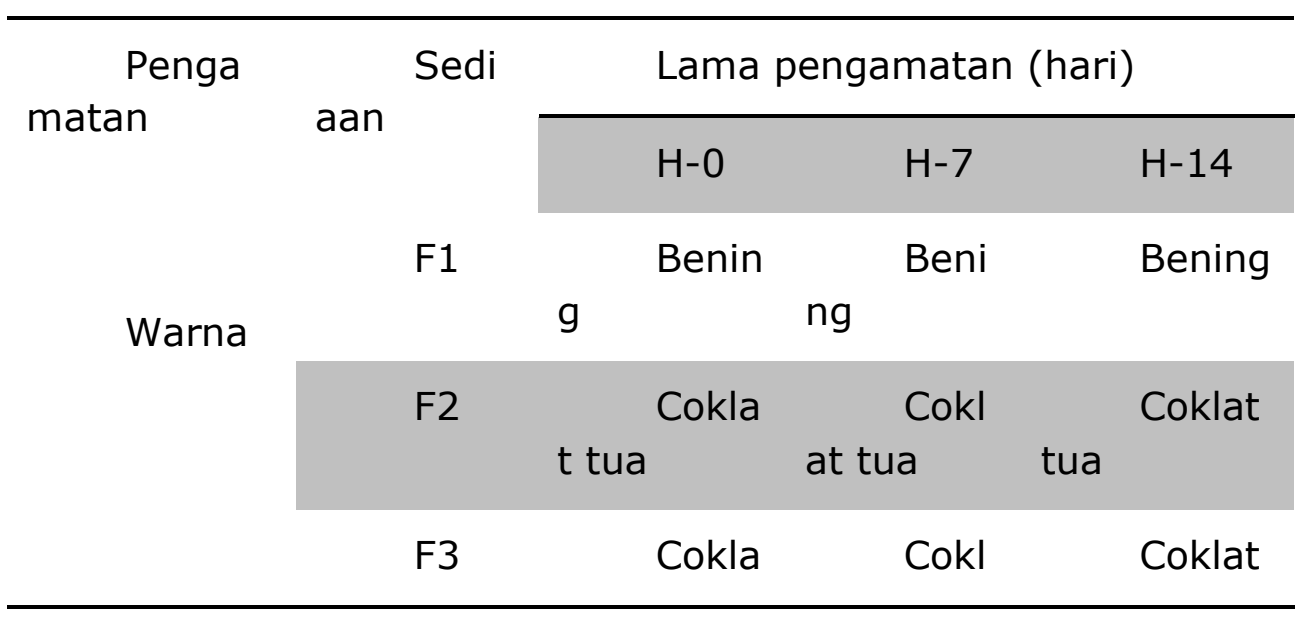




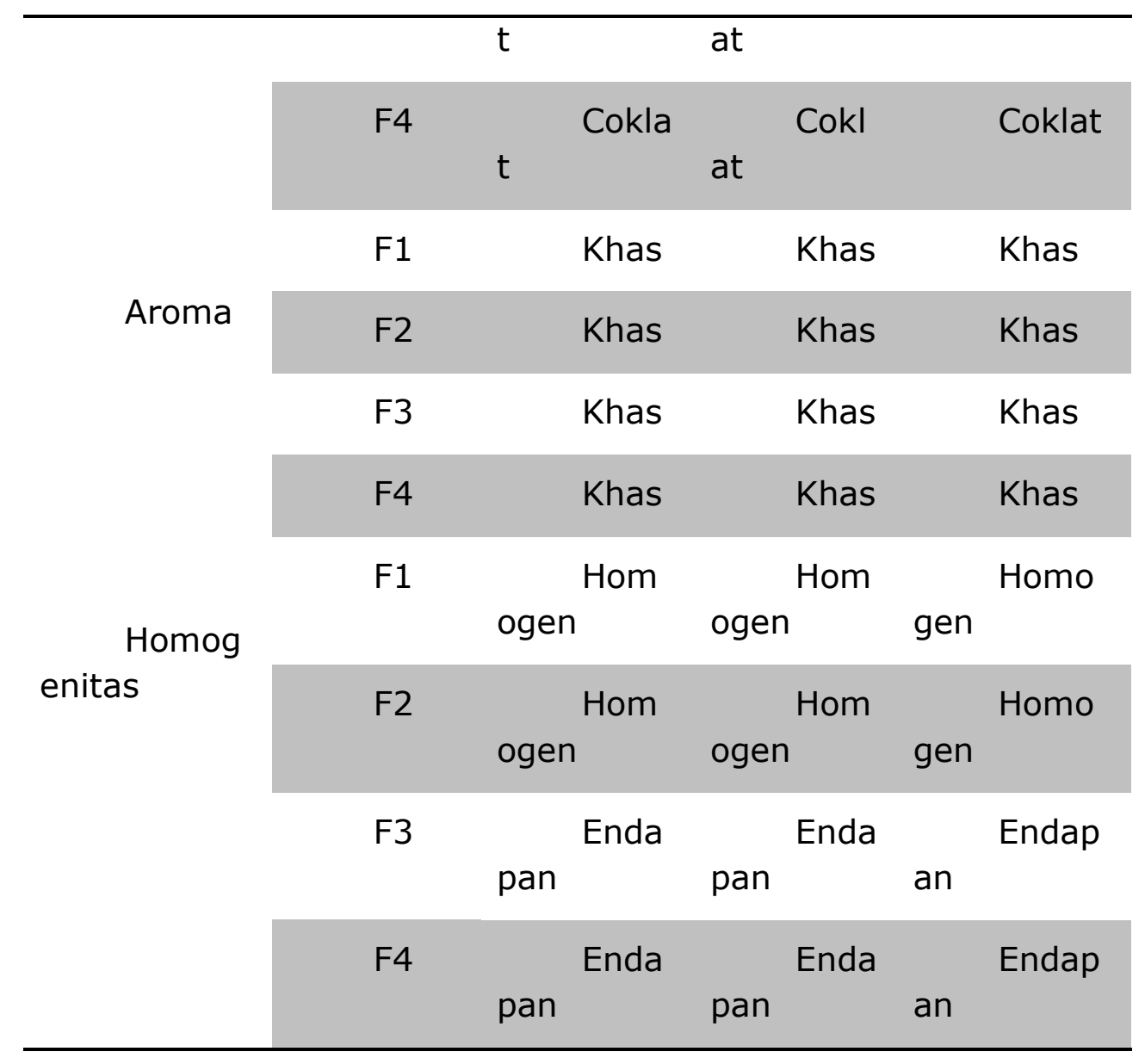

Tabel 4. $\mathrm{pH}$ sediaan obat kumur

\begin{tabular}{|c|c|c|c|c|}
\hline $\mathrm{pH}$ se & & & & \\
\hline ulasi ${ }^{\text {Form }}$ & $\mathrm{H}-\mathrm{O}$ & $\mathrm{H}-7$ & 14 & $\mathrm{H}-$ \\
\hline $\mathrm{F} 1$ & 8,03 & 6,10 & 52 & 6 \\
\hline $\mathrm{F} 2$ & 6,10 & 5,38 & 80 & 5, \\
\hline F3 & 5,20 & 4,85 & 02 & 5 \\
\hline $\mathrm{F} 4$ & 4,10 & 4,23 & 50 & 4 \\
\hline
\end{tabular}




$$
\begin{aligned}
& \text { Keterangan: } \mathrm{F} 1=\text { Tanpa gambir } \\
& F 2=\text { dengan konsentrasi } 5 \% \\
& F 3=\text { dengan konsentrasi } 10 \% \\
& F 4=\text { dengan konsentrasi } 15 \%
\end{aligned}
$$

\begin{tabular}{|c|c|c|c|c|c|}
\hline \multirow{3}{*}{ aan } & \multirow{2}{*}{ Sedi } & (cp) & Nilai viskositas rata-rata pada hari ke- & rata & a hari ke- \\
\hline & & & $\mathrm{H}-1$ & $\mathrm{H}-7$ & $\mathrm{H}-14$ \\
\hline & $\mathrm{F} 1$ & & 1,00 & 1,10 & 1,20 \\
\hline & $\mathrm{F} 2$ & & 1,40 & 1,50 & 1,60 \\
\hline & F3 & & 2,20 & 2,30 & 2,40 \\
\hline & F4 & & 3,40 & 3,50 & 3,60 \\
\hline
\end{tabular}

Tabel 5. Hasil pengukuran viskositas

Keterangan: $\mathrm{F} 1=$ Tanpa gambir

$\mathrm{F} 2=$ dengan konsentrasi $5 \%$

F3= dengan konsentrasi 10\%

$\mathrm{F} 4=$ dengan konsentrasi $1 \%$

\section{PEMBAHASAN}

Tabel 3 menunjukkan bahwa sediaan $F 1$ berwarna bening karena tidak mengandung gambir, F2 dengan konsentrasi 5\% menunjukan warna coklat tua, sedangkan F2 dan F4 konsentrasi $10 \%$ dan $15 \%$ memberikan warna coklat, bertambahnya konsentrasi gambir yang digunakan maka menimbulkan endapan pada formula hal tersebutlah yang membuat warna menjadi coklat. Sediaan obat kumur yang dihasilkan berbau khas peppermint oil sebagai koringesia odoris (flavouring agent). Bau sediaan tetap stabil dalam penyimpanan selama 14 hari pengamatan pada suhu kamar. Hasil pengamatan bentuk, menunjukkan bahwa seluruh sediaan obat kumur yang dibuat memiliki bentuk fisik yang baik dan stabil.

\section{b. Pengukuran pH}

Angka $\mathrm{pH}$ suatu medium sangat mempengaruhi jenis bakteri yang dapat tumbuh. Kebanyakan bakteri mempunyai $\mathrm{pH}$ optimum yaitu sekitar $\mathrm{pH}$ 6,5-7,5 [10]. Oleh karena itu, nilai $\mathrm{pH}$ formulasi obat kumur gambir harus berada diluar range nilai $\mathrm{pH}$ optimum 
pertumbuhan bakteri (Anggraini, 2017), Pengujian $\mathrm{pH}$ sediaan obat kumur gambir dilakukan dengan menggunakan indikator $\mathrm{pH}$ elektrik. Hasil pemeriksaan terhadap $F 1$ tanpa gambir diproleh

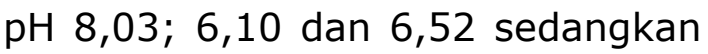
sediaan yang menggunakan gambir F2, F3 dan F4 pada konsentrasi 5\%, $10 \%$ dan $15 \%$ memiliki $\mathrm{pH} 6,10-$ 5,$80 ; 5,20-5,02 ; 4,10-4,50$. Dari tabel 4.5 dapat diketahui bahwa selama 14 hari penyimpanan nilai $\mathrm{pH}$ dari keempat formulasi tersebut berbeda-beda. $\mathrm{pH}$ pada sediaan obat kumur gambir cendrung asam, hal ini dipengaruhi oleh $\mathrm{pH}$ dari bahan tambahan yang digunakan serta gambir yang diberikan konsentrasi semakin tinggi maka akan semakin rendah $\mathrm{pH}$ sediaan. Menurut (Anggraini, 2017), pH sediaan obat kumur yang dapat diterima adalah 4,0-6,5.

Hasil analisis nilai $\mathrm{pH}$ pada sediaan diketahui bahwa nilai $\mathrm{pH}$ berada diluar range $\mathrm{pH}$ optimum pertumbuhan bakteri, sehingga formulasi obat kumur gambir ini dapat menghambat pertumbuhan bakteri yang ada di rongga mulut, terutama bakteri Streptococcus aureus yang termasuk salah satu penyebab penyakit sariawan. Maka dalam hal ini dapat disimpulkan bahwa $\mathrm{pH} F 1, \mathrm{~F} 2$ dan F3 pada sediaan obat kumur yang dibuat memiliki $\mathrm{pH}$ yang dapat diterima.

\section{c. Pengukuran viskositas}

Viskositas formulasi obat
kumur sangat mempengaruhi
terhadap tingkat kekentalan produk
tersebut saat digunakan berkumur
di dalam mulut. Semakin dekat

tingkat viskositas suatu produk formulasi mouthwash dengan tingkat viskositas air, maka semakin mudah dan nyaman produk tersebut digunakan untuk berkumur. Viskositas air sebagai standar pada perhitungan viskositas adalah sekitar $\pm 1 \quad \mathrm{CP}$ Hasil pengujian viskositas sediaan mouthwash sebesar 1,27-1,82 cP (Anggraini, 2017).

Oleh karena itu dapat diketahui bahwa semakin besar konsentrasi gambir yang digunakan maka akan semakin besar pula nilai viskositasnya. Hal ini terjadi karena penggunaan serbuk gambir yang terdiri atas partikel-partikel halus terlarut, sehingga dapat meningkatkan nilai viskositas pada obat kumur yang dihasilkan. Selain ekstrak, bahan tambahan yang digunakan juga mempengaruhi viskositas sediaan (Anggraini, 2017).

\section{Pengujian efektivitas antibakteri dalam formulasi obat kumur gambir}

Diameter zona hambat bakteri akan semakin bertambah luas dengan adanya peningkatan konsentrasi gambir yang diuji, sehingga diantara peningkatan konsentrasi gambir akan berbanding lurus dengan peningkatan zona hambat bakteri Staphylococcus aureus. Menurut david dan stout (1991), suatu larutan memiliki aktivitas berdasarkan diameter hambatnya adalah $20 \mathrm{~mm}$ atau lebih termasuk kategori sangat kuat, daerah hambatan 10-20 mm kategori kuat, daerah hambatan 5-10 mm 
kategori sedang dan daerah hambatan $5 \mathrm{~mm}$ atau lebih termaksuk kategori lemah.

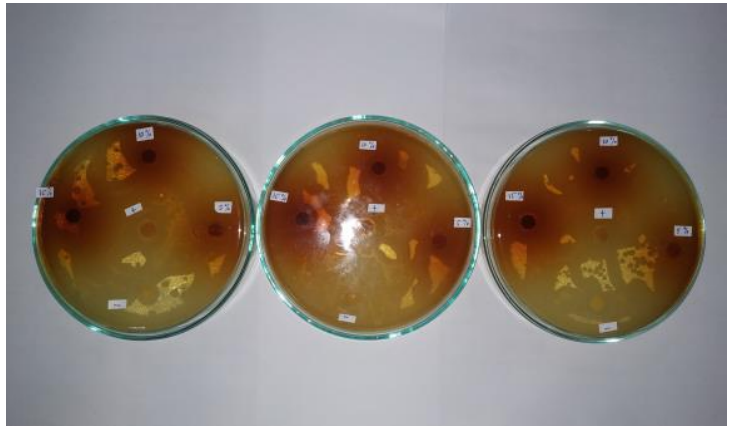

Gambar 1. Hasil Pengujian efektivitas antibakteri.

Tabel 6. Hasil rata-rata diameter daerah hambatan sediaan obat kumur gambir

\begin{tabular}{|c|c|c|}
\hline Formul & $\begin{array}{l}\text { Konsentrasi } \\
(\mathrm{gr} / \mathrm{mL})\end{array}$ & $\begin{array}{l}\text { Diameter daerah } \\
\text { hambatan } \\
\text { Staphylococcus aureus } \\
(\mathrm{mm})^{*}\end{array}$ \\
\hline $\mathrm{F} 1$ & - & 0 \\
\hline $\mathrm{F} 2$ & 5 & 5,46 \\
\hline F3 & 10 & 9,60 \\
\hline $\mathrm{F} 4$ & 15 & 10,76 \\
\hline $\begin{array}{l}\text { Kontrol } \\
\text { positif }\end{array}$ & - & 12,10 \\
\hline
\end{tabular}

Keterangan: $*=$ hasil rata- rata

$0=$ tidak ada hambatan

$\mathrm{F} 1=$ Tanpa gambir

$\mathrm{F} 2=$ dengan konsentrasi $5 \%$

$\mathrm{F} 3=$ dengan konsentrasi $10 \%$

$\mathrm{F} 4=$ dengan konsentrasi $15 \%$

diperoleh pada $\mathrm{F} 1$ tanpa gambir diameter zona hambat tidak ada, F2 konsentrasi $5 \mathrm{gr} / \mathrm{mL}$ diameter zona hambat pada bakteri Staphylocoocus aureus $(5,46 \mathrm{~mm})$, pada F3 konsentrasi $10 \mathrm{mg} / \mathrm{mL}$ diameter zona hambat pada bakteri Staphylocoocus aureus $(9,60 \mathrm{~mm})$, 
pada F4 konsentrasi $15 \mathrm{gr} / \mathrm{mL}$ diameter zona hambat pada bakteri Staphylocoocus aureus $(10,76 \mathrm{~mm})$ sedangkan pada kontrol positif yaitu menggunakan povidone iodine diameter zona hambat pada bakteri Staphylocoocus aureus $(20,10 \mathrm{~mm})$.

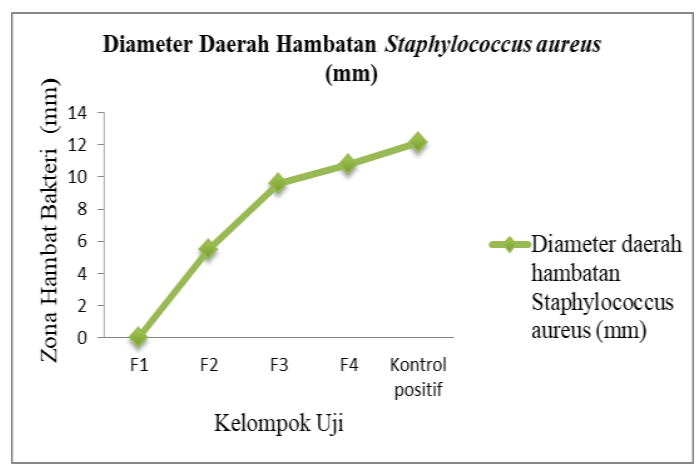

Gambar 2. Grafik diameter daerah hambat Staphylococcus aureus

Grafik diatas menunjukan bahwa zona hambat terbesar terdapat pada kontrol positif, hal tersebut disebabkan karna povidone iodien memiliki efek antibakteri yang kuat. Kelompok F4 merupakan kelompok uji yang merupakan zona hambat paling besar karna memiliki konsentrasi gambir tertinggi. Sedangkan kelompok F3 dan F2 memiliki zona hambat yang paling kecil dari F4 karna memiliki konsentrasi gambir paling sedikit. Sedangkan F1 tidak menunjukan adanya zona hambat karna pada F1 tidak menggunakan konsentrasi gambir.

\section{KESIMPULAN}

Berdasarkan hasil penelitian ini dapat disimpulkan bahwa obat kumur gambir dapat menghambat pertumbuhan bakteri Staphylococcus aureus.

\section{DAFTAR PUSTAKA}

Aditya, M., Ariyanti, R,P. (2016). Manfaat Gambir (Uncaria gambir Roxb) sebagai Antioksidan. Lampung : Jurnal Uiversits Lampung vakultas kedokteran, Vol. 5, No. 3.

Almasyhuri., Sundari, D. (2018). Uji Aktivitas Antiseptik Ekstrak Etanol Daun Sirih (Piper betle Linn.) dalam Obat Kumur terhadap Staphylococcus aureus secara in Vitro. Jakarta: Jurnal Kefarmasian Indonesia, vol. 9, No. 1. Halaman 11.

Anastasia, A,. Yuliet., Tandah, R, M. (2017). Formulasi Sediaan Mouthwash Pencegah Plak Gigi Ekstrak Biji Kakao (Theobroma cacao L) dan Uji Efektivitas pada Bakteri Streptococcus mutans. Palu: Journal of Pharmacy, Vol. 3, No.1. Halaman 85.

Anggraini, K, S. (2017). Uji Aktivitas Antibakteri dari Ekstrak Etanol Kulit Batang Sikkam (Bischofia javanica Blume) dan dalam Sediaan Obat Kumur. Medan: Skripsi Fakultas Farmasi Universitas Sumatera Utara, halaman 28.

David, W.W and Stout, T.R., (1971). Disc Plate Methods of Microbiological

Antibiotic Assay. Microbology. 22(4): 659-665

Hidayat. (2015). Kitab Tumbuhan Obat. Jakarta: Penebar Swadaya. Halaman 180. 
Ningrum, A, W., Waznah, U. (2018). Formulasi Mouthwash Ekstrak Etanol Daun Kemangi (Ocimumbasilicum L.). Pekalongan: Journal of Pharmacy Vol. 2, No.2. halaman 162, 164

Pambayun., Gardjito, G. (2018). Sensitivitas Bakteri Gram Positif Terhadap Katekin Yang Diekstraksi Dari Gambir (Uncaria Gambir). Palembang: Agritech, Vol. 28, No. 4. Halaman 175.

Sandy, M, P., Irawan, B, F. (2018). Perkembangan Obat SariawandanTerapi Alternatifnya. Sumedang: jurnal farmasi vol.3, No.5. halaman 98.

Syamsuni. (2006). IImu Resep. Jakarta: Penerbit Buku Kedokteran EGC.Halaman 101. 